\title{
The European Oral Health Indicators and Challenges in Prevention of the Major Dental Diseases in Children of the Commonwealth of Independent States
}

\author{
P.A. Leous \\ MD, PhD, DMSci, Professor, Belarusian State Medical University, Minsk, Belarus
}

\begin{abstract}
The aim of the study is to asses the prevalence of dental caries and common risk factors among school age cildren in the Commonwealth of Independent States (CIS countries) in order to base recommendations to improve the primary prevention. Objects and methods. Meta-analysis of the dental literature and own research data on the analytical epidemiology on dental caries in cildren.

Results and discussion. In the most CIS countries, a reduce dental caries trend was observed in recent 20-25 years due to the Prevention Program which was introduced in 1988. However, dental caries level in CIS is much higher of the best international standards.

Conclusions. The challenges in promotion of primary prevention in CIS countries should be an exchange of experience and use of the WHO recommendations.
\end{abstract}

\section{Европейские индикаторы стоматомогического зАоровья и перспективы профимактики кариеса зубов у детей стран СНГ}

\author{
П.А. $\Lambda$ eyc \\ A-р меА. наук, профессор, Белорусский государственный медицинский университет, Минск, Беларусь
}

Резюме. Цель исследования. Эпидемиология основных стоматологических болезней среди детского населения стран СНГ, сравнение полученных данных на региональном уровне и выявление социально-поведенческих факторов риска возникновения этих болезней.

Объекты и методы. Аналитическая эпидемиология в Беларуси и странах СНГ с использованием системы EGOHID (Европейские индикаторы стоматологического зАоровья). Нами организовано исследование более 2 тысяч детей школьного возраста в 20 местностях восьми стран, с участием ведущих ученых-стоматологов стран СНГ. Проведен метаанализ межАународной научной стоматологической митературы по эпидемиологии кариеса зубов.

Результаты и обсуждение. Несмотря на значительное улучшение стоматологического здоровья населения в ряде стран, на региональном уровне все еще существует проблема высокой интенсивности кариеса зубов у Аетей. СреАний КПУ зубов 12-летних детей варьирует от 1.0 Ао 5.0. Неудовлетворительный стоматологический статус оказывает существенное вАияние на общее зАоровье и качество жизни мюдей разных возрастных групп. Различия в распространенности и тенденциях стоматологических болезней в странах и регионах отражают возможные риски и влияют на реализацию программ профилактики. В дополнение к плохим условиям проживания и факторам риска, связанным с нездоровыми привычками (например, неправильная диета, плохая гигиена рта), на ухудшение стоматологического зАоровья может вАиять неАостаточная доступность стоматологической помощи. РяА стоматологических болезней непосреАственно связан с системными неинфекционными заболеваниями, имеющими общие факторы риска.

Заключение. Выявлены достоверные взаимосвязи поведенческих факторов риска и высокой интенсивности кариеса зубов у Аетей школьного возраста стран СНГ. На межгосударственном уровне необходимы интегральные программы профилактики, первичной медико-санитарной помощи и обеспечения здоровья. Опыт реализации программы профилактики стоматологических заболеваний в Беларуси может быть использован в Аругих странах.

Ключевые слова: аналитическая элидемиология, система EGOHID, кариес зубов, социально-поведенческие фракторы риска, программы профилактики 
$\mathrm{D}$ ental caries is caused by the demineralization of the enamel byorganic acids that are produced by the microorganisms of the dental plaque. In experiment, caries does not exist in sterile conditions. Therefore, this disease is considered to be infection, that is clinically manifested as the form of a gradual destruction of hard tooth tissue with a number of conditions. The first and proved condition is reduced resistance of mineral teeth substance to destructive effects of acid that occurs in case of insufficient intake of fluoride in the body and the presence of the substrate - carbohydrate food to produce acids. Analyzing these three factors (microorganisms, carbohydrate and fluoride deficiency) we can explain the known evolution of caries from ancient times to the present day, as well as the variability in the prevalence and intensity of caries disease in the population of the globe. So, it is very important to evaluate these three factors in complex. Thus, poor oral hygiene, or its absence, does not destroy the teeth if they are protected by fluoride, observed food intake regime and/or absence of the sugar in the diet. Another situation: eating sweets does not cause tooth decay, if regularly and thoroughly clean your teeth with fluoride toothpaste. So, the primary prevention is built on these features of caries etiopathogenesis. It's successful, if we exclude or minimize the effect of all three risk factors of dental caries; it's not effective enough, if any of this factors hasn't been neutralized and is not effective at all if all the factors remain active. It follows that the ideal toothbrushing with the toothpastes without fluoride or mineral supplements do not reduce the susceptibility of dental caries as well as the limiting the consumption of sugary foods without careful and regular oral hygiene is not one of the components of the effective prevention program.

In the scientific dental literature of Commonwealth of Independent States (CIS) in many studies were efforts to identify possible causes of the lack of clinical efficacy of prevention programs with a focus on deficit financing, the lack of specialized staff (dental hygienists), the reluctance of the population, denial of the use of fluoride as a potentially harmful substance. There are numerous proposals for a new methods and products, however, they have not been tested at the community level [8].

\section{THE AIM OF THE RESEARCH}

The aim of the study was the comparative evaluation of the prevalence of dental caries in the population of the CIS countries and the identification of the key factors that are influence on the variability of caries intensity among schoolage children.

\section{- OBJECTS AND METHODS}

We held a meta-analysis of the literature and our own previously published data of descriptive epidemiology of dental caries in the CIS countries. In 2013 - 2016 years International pilot project was organized in 19 locations (including capitals and major cities) in eight countries: Armenia, Belarus, Georgia, Kazakhstan, Kyrgyzstan, Moldova, Russia, Ukraine. The analytic epidemiology of dental caries and periodontal diseases included the use of international system EGOHID-2005 (European Global Oral Health Indicators Develohment), the WHO oral health assessment forms and questionnaires 2013. The study was supported by distinguished scientists of these countries. Basic dental health indicators data of the school age children of two key ages of 12 and 15 years were published in dental journals of CIS $[4,5,7,9,10,14,15,18,21,25]$.

\section{RESULTS AND DISCUSSION}

Data analysis of the descriptive epidemiology of dental caries in Europe showed a significant difference in the intensity of the DMFT in key age group of 12-year-olds between the Western, Central and Eastern regions. On the symbolic map is clearly shown that in the CIS countries the intensity of the caries of 12-year-old children is about 2 times higher than in Western Europe (fig. 1) [23]. This reflects the differences in the effectiveness of prevention programs, especially in view of the fact that in 1960-70 th in most Western European countries caries susceptibility of school age children was in 2-3 times higher than in the republics of the former USSR. A more detailed data of monitoring of the caries intensity in key age groups of children in the CIS countries presented in the table 1 and fig. 2 .

In 2013 we have initiated an intercountry pilot project "European oral health indicators" in which the basic criteria of dental health and risk factors of school children were studied in nineteen locations in eight countries (table 2).

In increasing order the fig. 5 presents the DMFT averages of permanent teeth of 12-yearolds in the surveyed areas in CIS. The variability in the level of DMF is considerable: $1-1.2$ in Poltava and Tiraspol, to $4.7-4.8$ in Moscow and Ternopol. If a low level of DMF in Poltava and Tiraspol can be attributed to the optimal or high content of fluoride in drinking water, in other areas fluoride content in drinking water is low. However, the differences of DMF of permanent teeth in 12-year-olds are significant: 


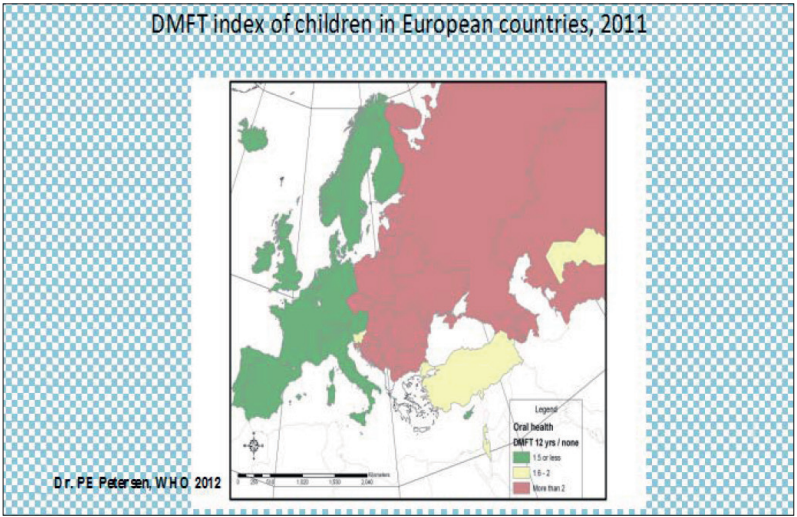

Fig. 1. The symbolic map of Europe showing the average DMFT of 12-year-old children (P.E. Petersen, 2010).

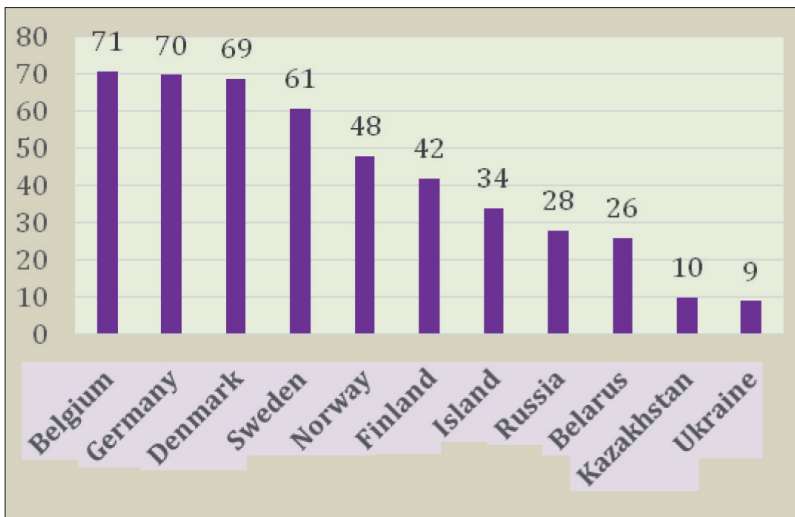

Fig. 3. Percentage of caries free 12-year-old children in selected EU and CIS countriers (ref. 26 and table1)

in Minsk and Tbilisi 1.8 - 2.0; in Bishkek, Omsk, Kiev 3.8 - 4.0. Fig. 6 summarizes the dynamics of the caries intensity in the CIS countries compared to Western Europe and the World. It can be seen a clear opposite downward trend DMFT

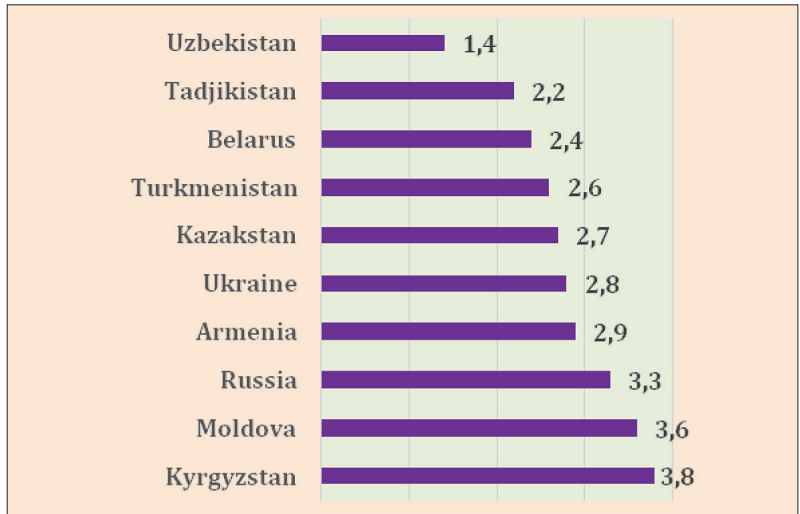

Fig. 2. Average DMFT of 12-year-olds in CIS countries, 2013-2016. (References in Table. 1.)

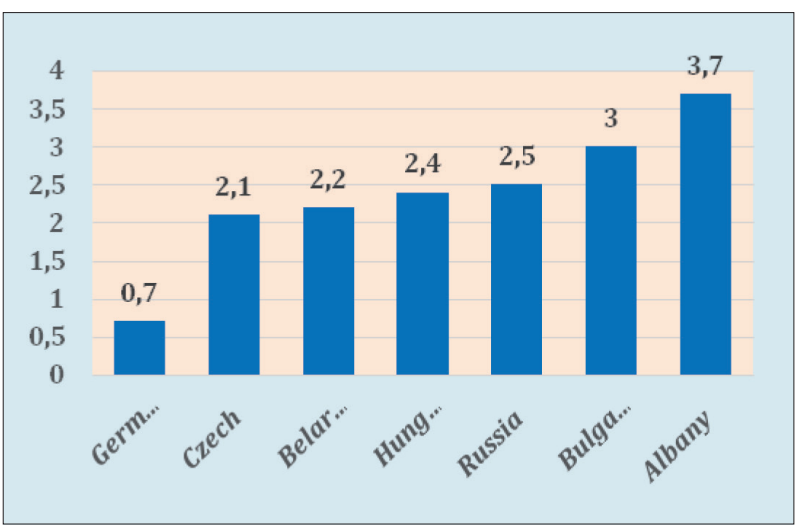

Fig. 4. Av. DMFT of 12-year-old children $[6,16,26]$

of 12-year-olds in Western Europe from 5.2 in 1970-80 to 0.9 years in 2016 and the increase of the intensity of the caries in the CIS countries from 2.2 to $2.8 \mathrm{DMFT}$, during monitoring period. Thus, the task of identifying risk factors and/

Table 1. DMFT data monitoring of 12-year-olds in the CIS countries, 1960 - 2016.

\begin{tabular}{|c|c|c|c|c|}
\hline \multirow{2}{*}{ Country } & \multicolumn{2}{|r|}{$1960-1980$} & \multicolumn{2}{|r|}{$2013-2016$} \\
\hline & DMFT & Reference & DMFT & Reference \\
\hline Azerbaijan & 3.1 & WHO CC, $1971[11]$ & & Publications unknown \\
\hline Armenia & 0.6 & $\begin{array}{l}\text { Eginyan G.M., } \\
\text { Melkumov V.A., } 1968 \text { [11] }\end{array}$ & 2.9 & Manrikyan M.E.,2013 [12] \\
\hline Belarus & 2.0 & Berdygan K.M., et al.,1966 [11] & 2.4 & Terekhova T.M., Melnikova E.I., 2015 [16] \\
\hline Kazakhstan & 2.0 & WHO CC, 1989 [11] & 2.7 & Ermuhanova G.T., et al. 2016 [2] \\
\hline Kyrgyzstan & 3.1 & WHO CC, 1973 [11] & 3.8 & Cholokova G.S., 2014 [19] \\
\hline Moldova & 1.5 & Yagudin A.D., 1967[11] & 3.6 & Lupan I., et al., 2015 [10] \\
\hline Russia & 3.5 & WHO CC, $1971[11]$ & 3.3 & Leous P.A., 2016 (average data of 18 publications) [8] \\
\hline Tajikistan & 1.2 & WHO CC, 1973 [11] & 2.2 & Turdyev B.Z., Hamadeeva A.M. 2016 [17] \\
\hline Turkmenistan & 1.5 & Rybakov A.I., 1975[11] & 2.6 & who.mah.se/country \\
\hline Uzbekistan & 2.3 & Yunusov Yu.Kh., 1966[11] & 1.4 & Shadiev K.K., 1997 [20] \\
\hline Ukraine & 3.4 & WHO CC, 1986[11] & $\begin{array}{l}2.8 \\
3.2\end{array}$ & $\begin{array}{l}\text { Marino B. et al., } 2012 \text { [22] } \\
\text { Khomenko L.A. et al.,2016 [18] }\end{array}$ \\
\hline CIS countries & 2.2 & & 2.8 & \\
\hline
\end{tabular}


Table 2. The reference data of intercountry pilot project.

\begin{tabular}{|c|c|c|c|c|c|c|}
\hline \multirow[t]{2}{*}{ Locality } & \multirow[t]{2}{*}{ Symbol } & \multicolumn{2}{|c|}{$\begin{array}{l}\text { Number of } \\
\text { surveyd }\end{array}$} & \multirow[t]{2}{*}{ Date (year) } & \multirow[t]{2}{*}{ Researchers } & \multirow[t]{2}{*}{ References } \\
\hline & & 12 years & 15 years & & & \\
\hline Almaty & A & 100 & 100 & 2016 & Ermuhanova G.T. & {$[2]$} \\
\hline Bishkek & B & 100 & 100 & 2013 & Kalbaev A.A. & [7] \\
\hline Voronezh & V & 100 & 100 & 2017 & Ippolitov Y.A. et al. & [3] \\
\hline Yerevan & Y & 100 & 101 & 2013 & Manrikyan M.E. & {$[12]$} \\
\hline Kiev & $\mathrm{KI}$ & 100 & 100 & 2016 & Khomenko L.A. et al. & [18] \\
\hline Kirov & KR & 250 & 250 & 2015 & Gromova S.N. et al. & [1] \\
\hline Chisinau & KS & 100 & 100 & 2014 & Spinei A., Spinei Yu. & {$[10]$} \\
\hline Lviv & $\mathrm{L}$ & 100 & 100 & 2013 & Smolar N.I. et al. & {$[15]$} \\
\hline Minsk & $\mathrm{Ml}$ & 260 & 185 & 2016 & Tserechova T.N. et al. & {$[16]$} \\
\hline Moscow & MO & 100 & 100 & 2013 & Kiselnikova L.P. et al. & [5] \\
\hline Novosibirsk & $\mathrm{N}$ & 150 & 150 & 2013 & Narykova A.A. & [7] \\
\hline Odessa & $\mathrm{OD}$ & 50 & 50 & 2013 & Denga O.V., Kosenko D. & [7] \\
\hline Omsk & OM & 100 & 100 & 2016 & Skripkina G.I. & [14] \\
\hline Poltava & $\mathrm{P}$ & 100 & 100 & 2016 & Kaskova L.F. et al. & [4] \\
\hline Samara & $\mathrm{S}$ & 102 & 100 & 2013 & Khamadeeva A.M. et al. & [7] \\
\hline St. Petersburg & SP & 348 & 353 & 2014 & Satygo E.A. & {$[5]$} \\
\hline Tbilisi & TB & 100 & 100 & 2014 & Margvelashvili M. et al. & {$[24]$} \\
\hline Ternopol & TE & 100 & 100 & 2013 & Lucinschi M.A. et al. & {$[15]$} \\
\hline Tiraspol & $\mathrm{Tl}$ & 300 & 300 & 2013 & Riabtseva I.M. & {$[13]$} \\
\hline
\end{tabular}

or the characteristics of the implementation of community programs for prevention in different regions of Europe is very important to share experiences and to optimize prevention.

It was mentioned above of the pathogenic role of three risk indicators of the tooth decay: fluoride deficiency, microbial plaque and the substrate. Therefore, this study is focused on the assesssment of these factors. In a series of studies in the framework of EGOHID intercountry project in nineteen locations were found that in the CIS countries only $48 \%$ of 15 -year-olds follow the recommended regimen of 2 times daily toothbrushing; only $33 \%$ of teenages use fluoride toothpastes, but quite a lot $-52 \%$ of the children daily consume sweet food (fig. 7). Fig. 8 shows the data of prevalence of one of the most important preventive measures among students of the CIS countries - toothbrushing. Large difference in the use of this method of prevention in different areas is obvious: from $22-24 \%$ in Tiraspol and St. Petersburg to $84 \%$ in Novosibirsk. Fig. 9 and 10 show how this factor can affect the percentage of children free of dental caries and the prevalence of gingival bleeding in adolescents.

Table 3, fig. 11 and 12 show detailed data on the use of fluoride toothpaste among 15-yearolds, the relationships of this factor with the intensity of dental caries, as well as the prevalence of other risk indicator - frequent consumption of sugary foods and drinks. It is important to note that in some cases the relationship of risk factors and dental caries can not be traced, hence the need for a comprehensive assessment of all three indicators.

Data of analytic epidemiology that we have obtained as a result of intercountry research project using EGOHID system convincingly confirmed the conclusiveness of the main determinants of dental caries: 1) microbial plaque, 2) frequent consumption of sugary foods and drinks, and 3) fluoride deficiency. The main determinant of periodontal diseases is a microbial plaque, that becomes pathogenic in case of absence or poor oral hygiene. Evidence of determinants of periodontal diseases and dental caries allows to confirm an evidence-based choice for primary prevention methods, that are fluorides, oral hygiene and a balanced diet. The most rational ways of practical implementation of these methods are: the use of fluoride toothpaste for 2-times daily toothbrushing and the limit of carbohydrate foods to 5-6 times a day. This approach does not deny many other risk factors, as general as local. However, you must realistically assess the possibility of eliminating the negative impact of the environment, common diseases, heredity, etc.

These approaches have been used in the development and implementation of the National Programme for the primary prevention of dental caries and periodontal diseases among the population of the Republic of Belarus. The important component of the program was to determine the long-term, measurable prevention 


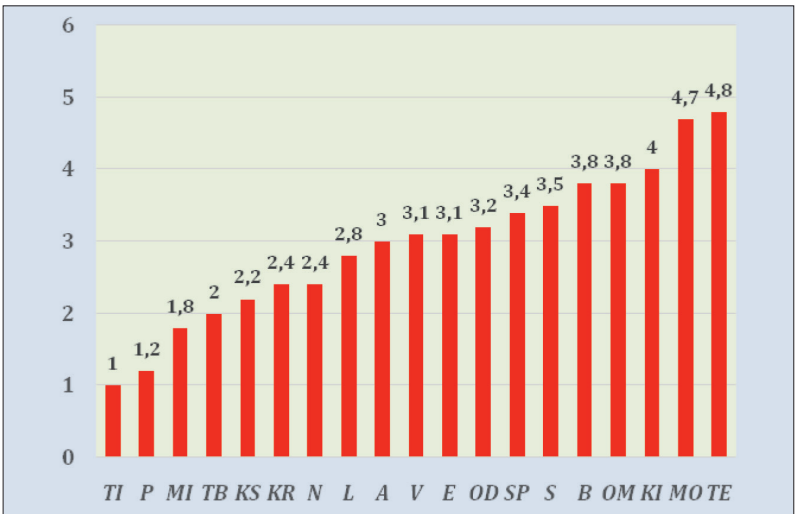

Fig. 5. Average DMFT of 12-year-olds in the nineteen localities of CIS (codes and references in table 2 )

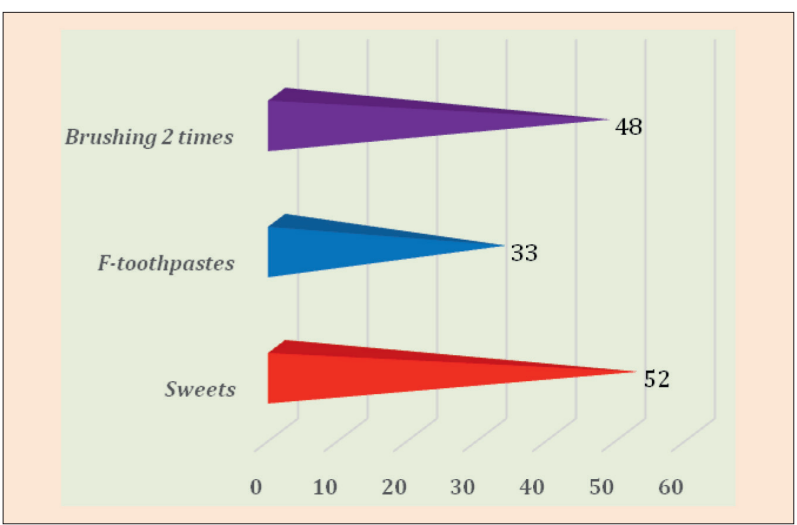

Fig. 7. Behavioral habits of 15-year-olg schoolchildren (\%) in CIS countries

goals (in concrete figures). For more effective therapeutic and preventive work among schoolage children were organized dental health centers together with obstetric and pediatric services. These centers were also carried out preventive work for children of preschool age.

The main componenst of the programme were training and daily toothbrushing under the supervision of the school teachers. Previously were held workshops with the school teachers. As part of the school curriculum were conducted health lessons, that formed knowledge about the prevention of dental diseases in future parents.

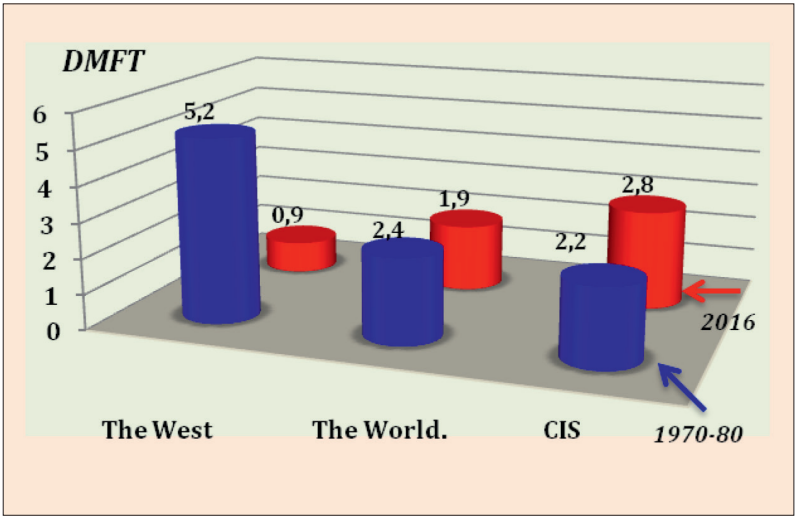

Fig. 6. Dynamics of intensity of dental caries of 12-year-olds in the CIS countries compared to Western Europe and the world (estimated data from the literature and our own research in the CIS countries)

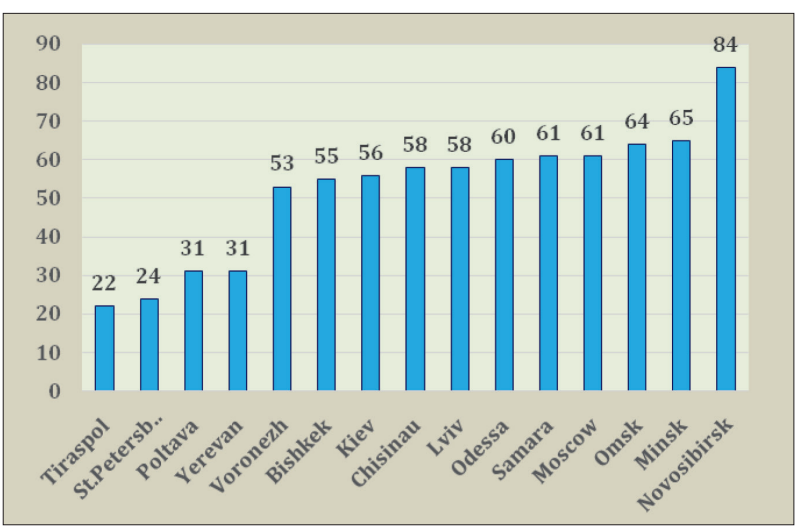

Fig. 8. Percentage of 15-year-olds practicing 2-times daily toothbrushing in the study localities in 2013-2017.

As a result of the implementation of prevention programme in Belarus during seventeen years (1997-2014) the intensity of dental caries of the key age group of children 12-year-olds decreased by $39 \%$, from DMF 3.8 to DMFT 2.3 (fig. 14). Fig. 13 shows an example of annual monitoring data of the DMFT of 12-year-olds in one of the districts of Minsk for the fifteen-years period from 2001 to 2015.

According to the recommendations of the World Health Organization, a national program of dental disease prevention should be based on continuous scientific support. Each country or

Table 3. Percentage of 15-year-olds using fluoride toothpaste

\begin{tabular}{|l|l|l|l|}
\multicolumn{1}{|c|}{ Location } & \multicolumn{1}{c|}{ \% of children } & \multicolumn{1}{c}{ \% of children } \\
\hline St. Petersburg & 87 & Bishkek & 29 \\
\hline Minsk & 75 & Voronezh & 24 \\
Novosibirsk & 66 & Lviv & 23 \\
Chisinau & 64 & Kiev & 26 \\
Almaty & 50 & Yerevan & 17 \\
Ternopol & 42 & Moscow & 17 \\
Odessa & 39 & Dushanbe & 16 \\
Samara & 33 & Kirov region. & 10 \\
Omsk & 31 & Poltava & 7
\end{tabular}




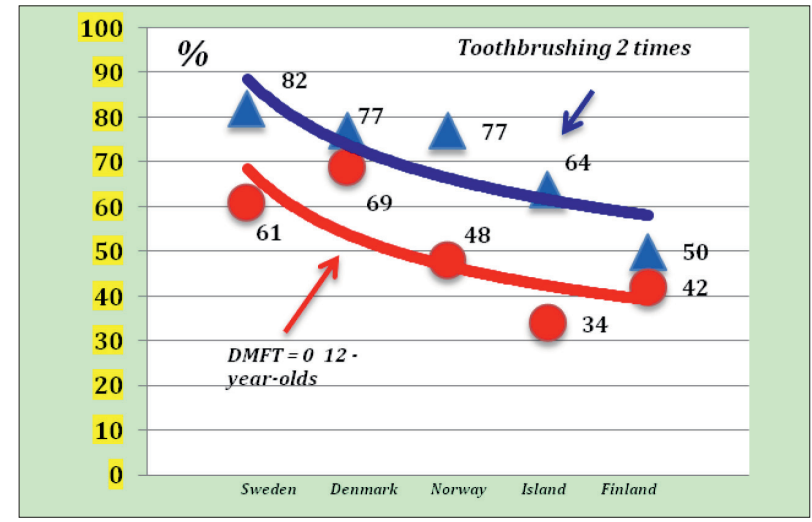

Fig. 9. Toothbrushing and caries-free 12-year-olds in Scandinavian countries www.thl.fi

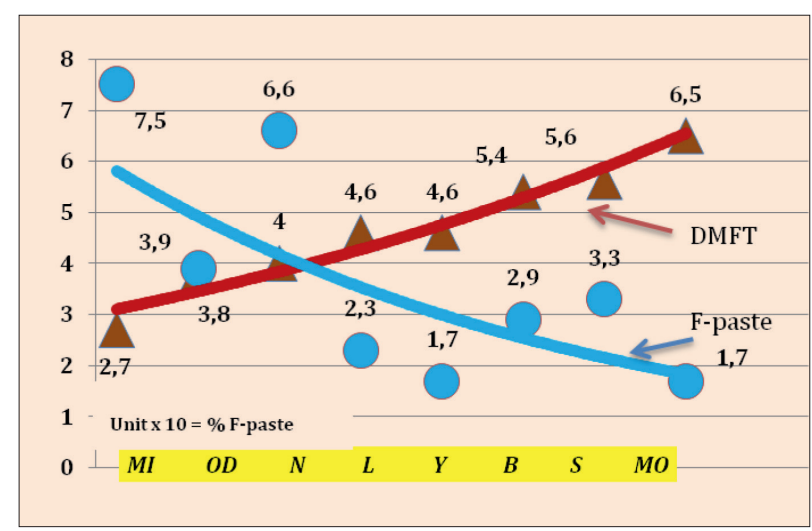

Fig. 11. DMFT and using F-toothpastes of 15-year-olds in CIS countries (countries codes see in table 2)

region has numerous features including lifestyle, behavioral habits of the population, and others. By the example of Belarus, the reduction in the intensity of dental caries among children has coincided with an increasing number of scientific works on prevention from 1996 to 2008. The sharp decrease in scientific support of the prevention programs has led to a certain increase in the incidence of children (fig. 15).

An extremely important aspect of the administration of prevention programms is its cost. It is believed that a reduction in dental diseases will reduce the cost of their treatment automatically and, therefore, the funds allocated to dental carewill be spared. However, preventive measures also have a certain value, that depends on the chosen methods of prevention. For example, the cost of "fissure sealing" roughly equivalent to feelling caries, or even more. Brushing your teeth with high-quality fluoride or mineral toothpaste is also not the cheapest method, but the acquisition of the oral hygiene does not have to be financed by the state, and if an event reduces the number of carious teeth, it can be assumed as cost-effective, or not expensive for the state. At the same time, should

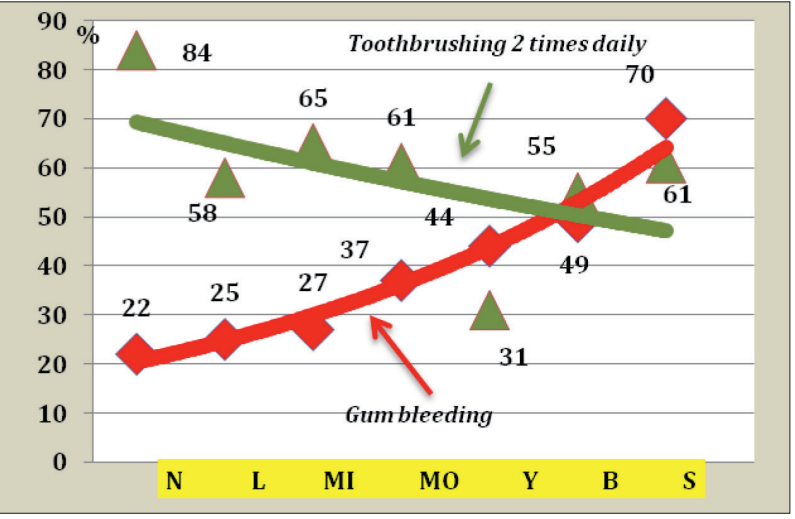

Fig. 10. Percentage of 15-year-olds practicing 2-times toothbrushing and having gum bleeding in selected CIS countries (countries codes see in table 2)

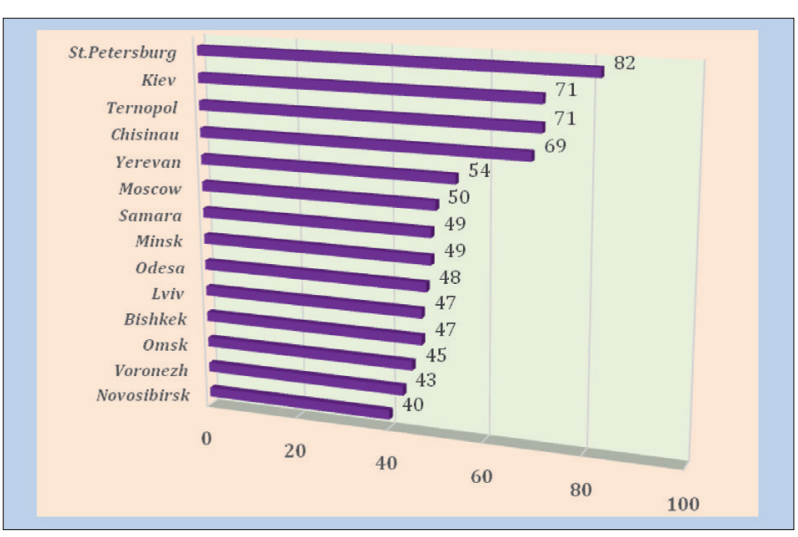

Fig. 12. 15-year-olds using daily sweets in the study localities in 2013-2017

not be confused medical and economic efficien$c y$, as the first provides health - the most precious thing a person can have. The motivation of the population to prevention has not been studied in the CIS countries because of the increasing cost of dental treatment. Thus, all the factors (fig. 16) should be taken in account during planning a cost-effectiveness of prevention programs.

The reasons for the lack of effectiveness of prevention. Implementation experience of municipal programs of primary prevention of major dental diseases in the countries of the former Soviet Union and the CIS countries have shown a lack of efficacy, that is evident when comparing the frequency of dental caries in children in Eastern and Western Europe (fig. 1). The main reasons for the lack of effectiveness of prevention programs, in our opinion, are:

- The lack of training of medical and dental staff about the prevention of dental diseases in community-level (in dental faculties there is no "Community Dentistry" subject)

- The absence or lack of public education on the individual methods of prevention of major dental diseases. 


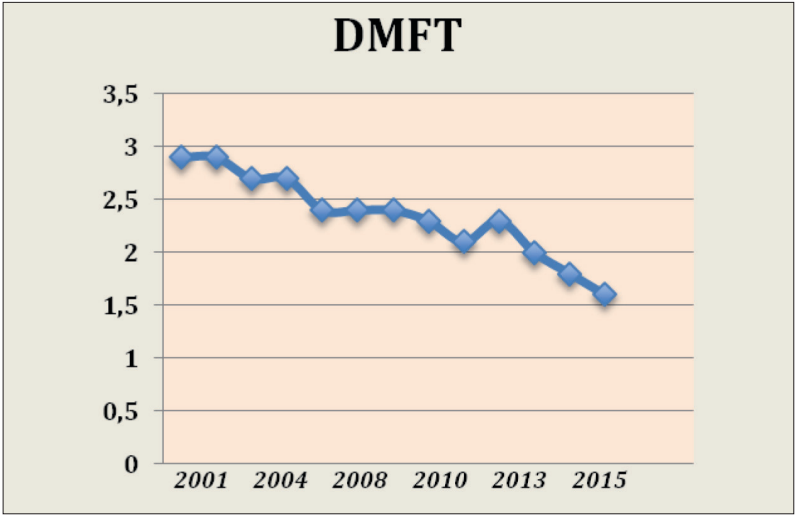

Fig. 13. DMFT monitoring (2001-2015) of 12-year-olds in Minsk

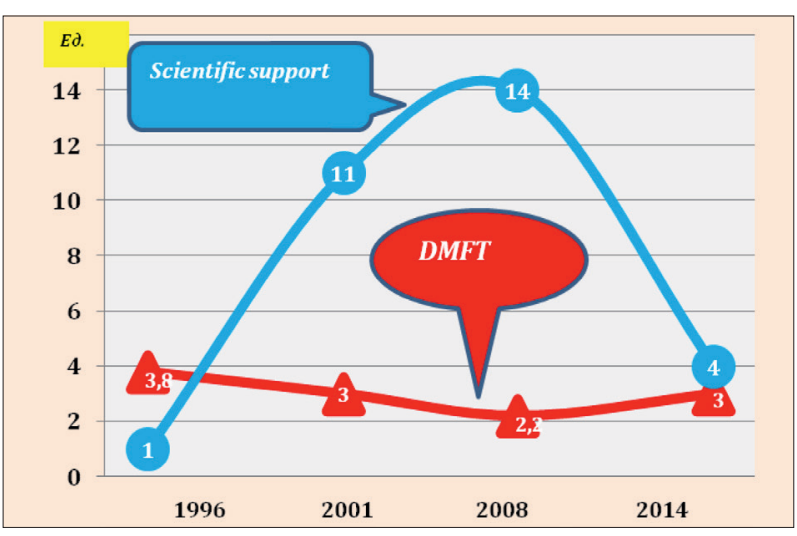

Fig. 15. Possible linkages of scientific support (number of defended dissertations on prevention issues) and the trend rate of dental caries in 12-year-olds in Belarus in 1996-2014yrs.

- Differences in recommendations of scientific schools and individual scientists on the organization and methods of prevention of dental caries and periodontal diseases.

- The lack of state monitoring (control) of the results of the primary prevention of dental diseases.

The confirmation of the first two states on the lack of effectiveness of prevention programs can be survey data of prevention programs in Belarus. Ignorance or other opinion on periodontal disease and dental caries prevention methods was among 10-20\% of dentists; 60 $80 \%$ of school teachers; $50-70 \%$ of the medical staff; $60-70 \%$ of preschool teachers; $70-80 \%$ of parents.

Objective incentive for program optimization utility for primary prevention of major dental diseases of caries and periodontal diseases in the CIS countries can be exchange of a good practice and the implementation of resolutions of the World Health Assembly, WHA 60.17 (2007), $\mathbb{\$} 7$ : Develop and implement a provision of oral health and prevention of dental diseases among pre-school children and schoolchildren in the framework of school health programs.

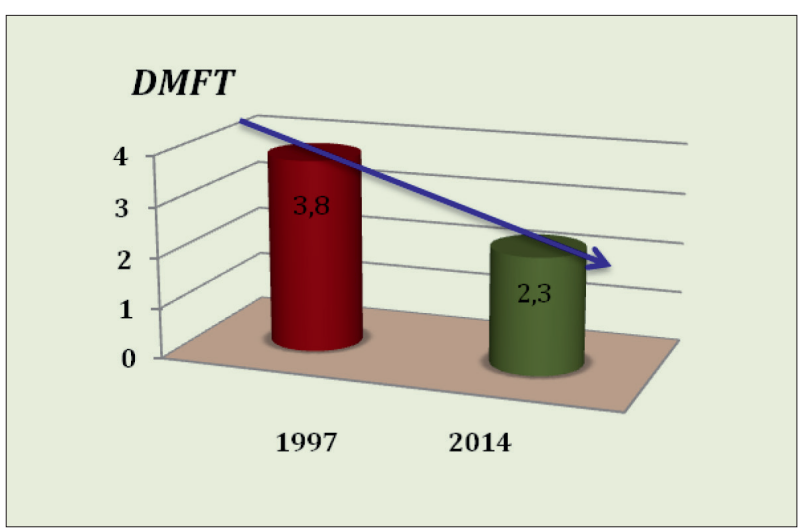

Fig. 14. Results of the state program of caries prevention in Belarus: the DMFT reduction in 12-year-old children

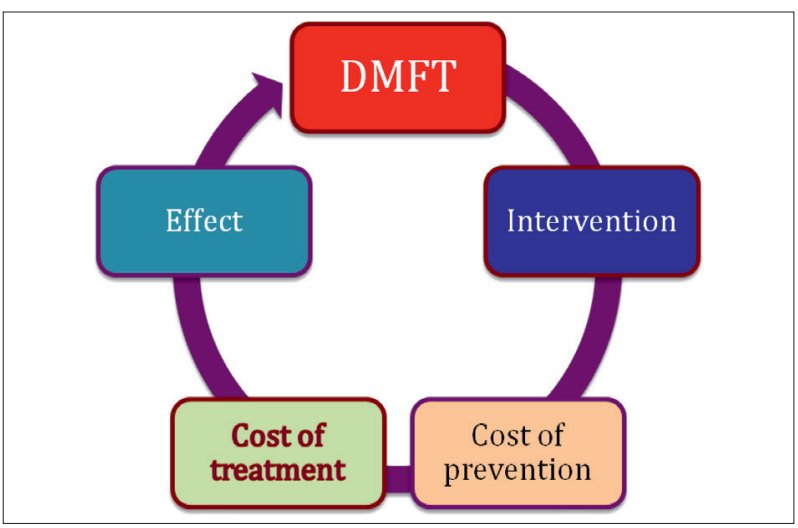

Fig. 16. Scheme of the interaction of various factors in determining the cost-effectiveness of prevention programs

\section{- CONCLUSION}

The analytic epidemiology intercountry research project in the CIS countries using EGOHID-2005 (European indicators of dental health) system, revealed behavioral risk factors for dental caries and periodontal diseases, that are caused by the non-observance of the recommended toothbrushing regime with fluoride toothpastes and a frequent consumption of sugary foods.

Evidence of risk indicators of periodontal disease and dental caries in children should be the basis for the choice of methods of prevention of these diseases. An effective organizational form of the practical implementation of community prevention programs is a daily (on school days) toothbrushing for the children 1-2 classes under the supervision of the teachers.

Optimizing primary prevention programs of major dental diseases of caries and periodontal diseases in the CIS countries is possible on the basis of exchange of experiences, as well as the implementation of the World Health Assembly resolution, WHA 60.17 (2007), \$ 7: "Develop and implement a provision of dental health and prevention of dental disease among pre-school children and schoolchildren in the framework of school health programs." 


\section{References}

1. Gromova S.N., Sinicyna A.V., Gavrilova T.A. Ocenka stomatologicheskoj zabolevaemosti shkol'nikov g. Kirova [Estimation of stomatological morbidity of schoolboys of Kirov]. Obozrenie stomatologii. RF. - Review of dentistry, RF. 2015, no. 3, pp. 42-44.

2. Ermuhanova G.T., Negametzjanov N.G., Rysbaeva Zh.I. O sostojanii stomatologicheskogo zdorov'ja detej Respubliki Kazahstan [On the state of dental health of children of the Republic of Kazakhstan]. Materialy mezhdunarodnoj nauchno-prakticheskoj konferencii [Materials of the international scientific-practical conference]. Omsk: OSMU, 2016, pp. 71-79.

3. Ippolitov Ju.A., Aleshina E.O. et al. Predvaritel'naja ocenka stomatologicheskogo statusa i povedencheskih faktorov riska u detej g. Voronezha, RF s pomoshh'ju evropejskih indikatorov [Preliminary assessment of dental status and behavioral risk factors in children in Voronezh, Russia with the help of European indicators]. Stomatologija detskogo vozrasta. RF. - Children's Dentistry, RF. 2017, no. 2 (61), pp. 84-88.

4. Kas'kova L.F. et al. Ocenka stomatologicheskogo zdorov'ja i vyjavlenie povedencheskih faktorov riska u detej g. Poltavy s pomoshh'ju evropejskih indikatorov [Evaluation of dental health and identification of behavioral risk factors in children of Poltava with the help of European indicators]. Vestnik problem biologii i mediciny. - Bulletin of the problems of biology and medicine. 2016, vol. 2, no. 2 (132), pp. 112-116.

5. Kisel'nikova L.P., Leus P.A., Satygo E.A. Sravnitel'naja ocenka evropejskih indikatorov stomatologicheskogo zdorov'ja detej shkol'nogo vozrasta v Minske, Moskve i Sankt-Peterburge [Comparative evaluation of European indicators of dental health of schoolchildren in Minsk, Moscow and St. Petersburg]. Stomatologicheskij zhurnal. - Dental Journal. 2015, vol. XVI, no. 1, pp. 27-31.

6. Kuz'mina Je.M. Stomatologicheskaja zabolevaemost' naselenija Rossii SC VOZ, Moskva [Stomatological incidence of the Russian population CC of WHO, Moscow]. MGMSU, 1999, 2009, 236 p.

7. Leus P.A., Den'ga O.V., Kalbaev A.A., Kisel'nikova L.P., Manrikjan M.E., Narykova A.A., Smoljar N.I., Spineĭ A.F., Hamadeeva A.M. Evropejskie indikatory stomatologicheskogo zdorov'ja detej shkol'nogo vozrasta [European indicators of dental health of school-age children]. Stomatologija detskogo vozrasta i profilaktika. - Children's dentistry and prevention. 2013, no. 4 (47), pp. 3-9.

8. Leus P.A. Otstupaet li karies u detej shkol'nogo vozrasta? [Does caries retreat in children of school age?] Obozrenie. Stomatologija (RF). - Review. Stomatology (RF). 2016, no. 1 (87), pp. 10-11.

9. Leus P.A., Homenko L.A., Smoljar N.I., Kas'kova L.F. Evropejskie indikatory v ocenke vlijanija povedencheskih faktorov riska na stomatologicheskoe zdorov'e detej shkol'nogo vozrasta [European indicators in assessing the impact of behavioral risk factors on dental health in school-age children]. Stomatologicheskij zhurnal. - Dental Journal. 2016, vol. XVII, no. 3, pp. 164-170.

10. Lupan I., Spinej A., Spinej Ju. Perspektivy monitoringa stomatologicheskogo zdorov'ja detej shkol'nogo vozrasta s pomoshh'ju evropejskih indikatorov [Prospects for monitoring the dental health of school-age children with the help of European indicators]. Bjulleten' Akademii nauk Moldovy Medicinskie nauki. Kishinev [Bulletin of the Academy of Sciences of Moldova]. 2015, no.1 (46), pp. 429-436.

11. Monitoring jeffektivnosti programm profilaktiki stomatologicheskih zabolevanij [Monitoring the effectiveness of programs for the prevention of dental diseases]. Moskovskij medicinskij stomatologicheskij institut SC VOZ, Moskva [Moscow Institute of Medicine and Dentistry CC of WHO, Moscow]. 1987, $18 \mathrm{p}$

12. Manrikjan M.E. Ocenka stomatologicheskoj zabolevaemosti naselenija Respubliki Armenija s uchetom mediko-social'nyh aspektov Diss. na soiskanie uchenoj stepeni dokt. med. nauk. Erevan [Assessment of the dental morbidity of the population of the Republic of Armenia taking into account medical and social aspects. Dr. medical. sci. diss.]. Yerevan, 2013, $187 \mathrm{p}$

13. Rjabceva I.M. Evropejskie indikatory v ocenke urovnja stomatologicheskogo zdorov'ja detej Pridnestrov'ja [European indicators in assessing the level of dental health of Transnistrian children]. Sbornik trudov II Rossijskogo regional'nogo kongressa Mezhdunarodnoj associacii detsko stomatologii (IAPD), Moskva [Collection of Proceedings of the II Russian Regional Congress of the International Association of Pediatric Dentistry (IAPD), Moscow]. 2014, pp. 122-126.

14. Skripkina G.I., Garifullina A.Zh. Ocenka stomatologicheskogo zdorov'ja detej shkol'nogo vozrasta s pomoshh'ju evropejskih indikatorov [Evaluation of dental health of school-age children with the help of European indicators] Stomatologija detskogo vozrasta i profilaktika (RF) Children's dentistry and prevention (RF) 2016, vol. XV, no. 3 (58), pp. 67-71.

15. Smoljar N.I., Leus P.A., Bezvushko Je.V., Luchinskij M.A., Chuhraj N.L. Opredelenie osnovnyh pokazatelej nedostatochnoj jeffektivnosti profilaktiki kariesa zubov i boleznej periodonta s pomoshh'ju Evropejskih indikatorov [Determination of the main indicators of the insufficient effectiveness of the prevention of dental caries and periodontal diseases with the help of European indicators]. Noviny stomatologii. Ukraina. News of stomatology, Ukraine. 2014, no. 3 (80), pp. 86-90.

16. Terehova T.N., Mel'nikova E.I. Jepidemiologicheskie pokazateli stomatologicheskogo statusa detskogo naselenija Respubliki Belarus' [Epidemiological indicators of the dental status of the child population of the Republic of Belarus]. Sbornik trudov III stomatologicheskogo kongressa Respubliki Belarus' [Collection of Proceedings of the III Dental Congress of the Republic of Belarus]. Minsk: BSMU, 2015 , pp. 109-111.

17. Turdyev B.Z., Hamadeeva A.M., Ganzha I.R. Ispol'zovanie evropejskih indikatorov stomatologicheskogo zdorov'ja u detej Respubliki Tadzhikistan [Use of European indicators of dental health in children of the Republic of Tajikistan] Sbornik nauchnyh trudov Jubilejnoj konferencii SamGMU [Collection of proceedings of the Jubilee Conference of SamSMU]. Samara: Publishing house "OFORT". 2016, pp. 420-425.

18. Homenko L.O., Leus P.A., Ostapko O.I., Sorochenko G.V. Opredelenie znachenija indikatorov riska pri raznyh urovnjah intensivnosti kariesa zubov u detej shkol'nogo vozrasta [Determination of the significance of risk indicators at different levels of tooth decay in children of school age]. Vestnik social'noj gigieny i organizacii zdorov'ja Ukrainy. - Bulletin of social hygiene and organization of health of Ukraine. 2016, no. 2 (68), pp. 39-45.

19. Cholokova G.S. Kliniko-jepidemiologicheskoe obosnovanie Nacional'noj programmy profilaktiki stomatologicheskih zabolevanij u detej v Kyrgyzskoj Respublike [Clinico-epidemiological basis of the National Program for the Prevention of Dental Diseases in Children in the Kyrgyz Republic. Dr. medical. sci. diss]. Bishkek. 2014, 204 p.

20. Shadiev K.K. Aktual'nye problemy razvitija stomatologicheskoj pomoshhi naseleniju Uzbekistana [Actual problems of the development of dental care for the population of Uzbekistan]. Tashkent: Shark Publishing House. 1997, 159 c.

21. EGOHID. Health Surveillance in Europe (2005). A Selection of Essential Oral Health Indicators. www.egohid.eu

22. Marino B., Domenico D., Igmazia C., Denga A. et al. Systems for the provision of oral health care in the Black See countries, Ukraine. Oral Health Dental Manag (Romania). 2012, vol. 11, pp. 149-161.

23. Petersen P.E. Improvement of global oral health - the leadership role of the World Health Organization. Community Dental Health. 2010, vol. 27, pp. 194-199.

24. Sgan-Cohen H.D., Margvelashvili V. et al. Dental caries among children in Georgia. Community Dent Health. 2014, Sep. no. 31(3), pp. 163-166. 25. World Health Organization. Oral Health Surveys Basic Methods, 5th Ed. WHO Geneva. 2013, 125 p.

26. WHO GODB www.mah.se/country

\section{- Литература}

1. Громова, С.Н. Оценка стоматологической заболеваемости школьников г. Кирова / С.Н. Громова А.В. Синицына, Т.А. Гаврилова // Обозрение стоматологии (РФ). - 2015. - № 3. - С. 42-44.

2. Ермуханова, Г.Т. О состоянии стоматологического здоровья детей Республики Казахстан / Г.Т. Ермуханова, Н.Г. Негаметзянов, Ж.И. Рысбаева // Материалы международной научно-практической конференции. Омский государственный медицинский университет, 3 Марта 2016, г. Омск (РФ). - 2016. - С. 71-79.

3. Ипполитов, Ю.А. Предварительная оценка стоматологического статуса и поведенческих факторов риска у детей г. Воронежа, РФ с помощью европейских индикаторов / Ю.А. Ипполитов [и др.] // Стоматология детского возраста (РФ). - 2017 - № 2 (61). - С. 84-88.

4. Каськова, Л.Ф. Оценка стоматологического здоровья и выявление поведенческих факторов риска у детей г. Полтавы с помощью европейских индикаторов / Л.Ф. Каськова [и др. ] // Вестник проблем биологии и медицины. - 2016. - Вып. 2, Том 2 (132). - С. 112-116.

5. Кисельникова, Л.П. Сравнительная оценка европейских индикаторов стоматологического здоровья детей школьного возраста в Минске, Москве и Санкт-Петербурге / Л.П. Кисельникова, П.А. Леус, Е.А. Сатыго // Стоматологический журнал. - 2015. - Т. XVI, № 1. C. 27-31. 
6. Кузьмина, Э.М. Стоматологическая заболеваемость населения России. / Э.М. Кузьмина / СЦ ВОЗ, МГМСУ: М.,1999, $2009 .-236$ с.

7. Леус, П.А. Европейские индикаторы стоматологического здоровья детей школьного возраста / П.А. Леус [и др.] // Стоматология

детского возраста и профилактика. - 2013. - № 4 (47). - С. 3-9.

8. Леус, П.А. Отступает ли кариес у детей школьного возраста? / П.А. Леус // Обозрение стоматологии (РФ). - 2016. - № 1 (87). - С. 10-11.

9. Леус, П.А. Европейские индикаторы в оценке влияния поведенческих факторов риска на стоматологическое здоровье детей школь-

ного возраста / П.А. Леус, Л.А. Хоменко, Н.И. Смоляр, Л.Ф. Каськова // Стоматологический журнал. - 2016. - Т. XVII, № 3. - С. $164-170$.

10. Лупан, И. Перспективы мониторинга стоматологического здоровья детей школьного возраста с помощью европейских индикаторов /

И. Лупан, А. Спиней, Ю Спиней // Buletinul Academiei de Stiinte a Moldovei Stiinte Medicale, Chisinau. - 2015. - № 1 (46). - С. 429-436.

11. Мониторинг эффективности программ профилактики стоматологических заболеваний. - Московский медицинский стоматологический институт, СЦВОЗ, Москва. - 1987, 18 с.

12. Манрикян, М.Е. Оценка стоматологической заболеваемости населения Республики Армения с учетом медико-социальных аспектов : дис. ... докт. мед. наук : М.Е. Манрикян - Ереван, 2013. - 187 с.

13. Рябцева, И.М. Европейские индикаторы в оценке уровня стоматологического здоровья детей Приднестровья / И.М. Рябцева // Сборник трудов II Российского регионального конгресса Международной ассоциации детской стоматологии (IAPD), 29.09-01.10.2014 г. МГМСУ. - Москва, 2014. - С. 122-126.

14. Скрипкина, Г.И. Оценка стоматологического здоровья детей школьного возраста с помощью европейских индикаторов /

Г.И. Скрипкина, А.Ж. Гарифуллина // Стоматология детского возраста и профилактика (РФ). - 2016. - Т. XV, № 3 (58). - С. 67-71.

15. Смоляр, Н.И. Определение основных показателей недостаточной эффективности профилактики кариеса зубов и болезней перио-

донта с помощью Европейских индикаторов / Н.И. Смоляр, П.А. Леус, Э.В. Безвушко, М.А. Лучинский, Н.Л. Чухрай // Новины стоматологии (Украина). - 2014. - № 3 (80). - С. 86-90.

16. Терехова, Т.Н. Эпидемиологические показатели стоматологического статуса детского населения Республики Беларусь /

Т.Н. Терехова, Е.И. Мельникова // Сборник трудов III стоматологического конгресса Республики Беларусь, г. Минск, 21-23 Октября 2015 г., БГМУ, Минск. - С. 109-111.

17. Турдыев, Б.З. Использование европейских индикаторов стоматологического здоровья у детей Республики Таджикистан /

Б.3. Турдыев, А.М. Хамадеева, И.Р. Ганжа // Сборник научных трудов Юбилейной конференции СамГМУ. Самара, РФ, Изд-во «ОФОРТ», 2016. - C. $420-425$.

18. Хоменко, Л.О. Определение значения индикаторов риска при разных уровнях интенсивности кариеса зубов у детей школьного возраста / Л.О. Хоменко, П.А. Леус, О.И. Остапко, Г.В. Сороченко // Вестник социальной гигиены и организации здоровья Украины. 2016. - № 2 (68). - C. $39-45$.

19. Чолокова, Г.С. Клинико-эпидемиологическое обоснование Национальной программы профилактики стоматологических заболеваний у детей в Кыргызской Республике : дисс. докт. мед. наук : Г.С. Чолокова. - Бишкек, 2014. - 204 с.

20. Шадиев, К.К. Актуальные проблемы развития стоматологической помощи населению Узбекистана / К.К. Шадиев. - Ташкент: Издательство «Шарк», 1997. - 159 с.

21. EGOHID. Health Surveillance in Europe (2005). A Selection of Essential Oral Health Indicators. www.egohid.eu

22. Marino, B. Systems for the provision of oral health care in the Black See countries, Ukraine / B. Marino, D. Domenico, C. Igmazia,

A. Denga [et al. ] // Oral Health Dental Manag (Romania). - 2012. - V. 11. - P. 149-161.

23. Petersen, P.E. Improvement of global oral health - the leadership role of the World Health Organization / Petersen P.E. // Community Dental Health. - 2010. - V. 27. - P. 194-199.

24. Sgan-Cohen, H.D. Dental caries among children in Georgia / Sgan-Cohen H.D., Margvelashvili V. [et al. ] // Community Dent Health. - 2014, Sep. - № 31 (3). - P. 163-166.

25. World Health Organization. Oral Health Surveys Basic Methods, 5th Ed. - WHO Geneva. - 2013. - 125 p.

26. WHO GODB www.mah.se/country

The authors presented the statement with the supplement of documents for the open publications / Авторами предоставлено заявление с приложением документов для открытой печати.

\section{THANKS}

This article is based on the analysis of research data in the framework of the pilot project "European dental health indicators" in 2013-2017 with the participation of known scientists and epidemiologists: Bezvushko E.V., Boyarkina E.S., Belenova I.A., Gigineshvili E. Denga O.V., Drobotko L.N., Ermuhanova G.T., Zhugina L.F., Ippolitov Y.A., Kaskova L.F., Kalbaev A.A., KiselnikovaL.P, KosenkoD.K., LucinschiM.A., NarykovaA.A., ManaschukN.V., ManrikyanM.E., Margvelashvili M., Melnikova E.I., Myshentsevoy A.P., Omelchenko A.V., Ostapko E.I., Sorochenko G.V., Ryabtseva I.M., Satygo E.A., Sinitsyn A.V., Skripkina G.I., Smolar N.I., Spinei A.F., Spinei Yu., Terekhova T.N., Turdyev B.Z., Filatova N.V., Khamadeeva A.M., Khomenko L.A., Chekalina T.D., Chukhray N.L. and the staff of pediatric dentistry faculties in CIS. 